\title{
Performance of Blast and Drought Tolerant Finger Millet Variety ML-365 under Front Line Demonstrations in Tumkur, Karnataka
}

\author{
K. R. Shreenivasa*, T. S. Sukanya and V. Govinda Gowda
}

ICAR- Krishi Vigyan Kendra, Konehally, Tiptur Tq Tumkur Dist Karnataka, India

*Corresponding author

\section{A B S T R A C T}

Frontline demonstrations were conducted in farmers' fields of Tumkur district of Karnataka, India during kharif 2016 to 2018 to create awareness among the farmers and demonstrate the improved production technologies in finger millet. The integrated crop management practices including cultivation of drought and blast tolerant finger millet variety ML 365, integrated nutrient management, integrated pest and disease management practices were demonstrated and compared with the existing farmers practice followed in Finger millet cultivation. Results showed that demonstration of finger millet variety ML 365 with integrated crop management practices recorded higher grain yield of $23.61 \mathrm{q} / \mathrm{ha}$ and farmers practice recorded lower yield of $18.46 \mathrm{q} / \mathrm{ha}$. Adoption of integrated crop management practices increased the grain yield of finger millet to the tune of 28.16 per cent compared to farmers practice. Farmers earned higher net income of Rs.34661/ha through the demonstration and Rs.21428/ha with farmers practice. Besides, farmers realized higher benefit cost ratio (2.66) through the demonstration compared to farmer's practice (2.10). Thus, the frontline demonstration of improved variety with crop management practices increased the grain yield and net income of the farmers growing finger millet under rainfed condition. In the present study, potential of the improved variety and technologies were demonstrated systematically and scientifically in the farmers field along with farmers practice for further adoption by farming community in large scale.

\section{Introduction}

Finger millet (Eleusine coracana L. Gaertn) is one of the important millets grown extensively in Tumkur District. It is a hardy crop, has good adaption to wide range of environment especially heat, drought, marginal and degraded soils (Okalebo et al., 1991). It is mainly grown for its grains and it is highly nutritious. Its grains contain carbohydrate $(65-75 \%)$, protein $(5-8 \%)$, dietary fibre (15-20\%), minerals (2.5-3.5\%) and vitamins (Chethan and Malleshi, 2007). It is superior to rice and wheat, in respect of crude fibre, amino acids and minerals like calcium $(344 \mathrm{mg} / 100 \mathrm{~g}$ ) and potassium (408 $\mathrm{mg} / 100 \mathrm{~g}$ ). It also contains anti nutrients such as phytates, polyphenols, tannins and trypsin inhibitory factors.

Regular consumption of whole grain of finger millet and its products helps in managing 
diabetes and its complications by regulation of glucose homeostasis and prevention of dyslipideamia. It also gives protection against the risk of cardiovascular disease, gastrointestinal cancers and other health issues. It has health beneficial effects, such as anti-diabetic, anti-diarrheal, antiulcer, antiinflammatory, antitumerogenic, atherosclerogenic effects, antioxidant and antimicrobial properties (Devi et al., 2014). Hence, there is a great demand for improving finger millet production.

Finger millet is being cultivated in an area of about 1,85,000 hectares in Tumkur District. About 90 per cent of the area under Finger millet is being cultivated under rainfed condition during kharif season. Under rainfed condition, farmers facing the problem of moisture stress at various crop growth stages thereby experiencing low yield and crop loss to some extent. Besides moisture stress, lack of knowledge on the availability of drought tolerant varieties, non adoption of improved cultivation practices, prevalence of nutrient deficiency, pest and disease incidence also lowers the finger millet productivity.

Hence, the productivity of finger millet might be increased by growing suitable variety along with improved crop management practices. Similar studies on crop yield increase by adoption of improved crop management practices were reported by Subhashree et al., (2017) in Finger millet; Sharma et al., (2016) and Singh (2017) in Wheat; Jat and Gupta (2015) in Pearl millet; Meena et al., (2014) in Maize

Considering the above facts, a frontline demonstration was proposed and conducted in the farmers' holdings to demonstrate the improved package of practices for higher productivity in finger millet under rainfed condition.

\section{Materials and Methods}

Frontline demonstration was conducted to demonstrate the potential of the drought and blast tolerant variety with the improved package of practices in comparison with the existing farmers practice in the farmers' holdings of Tumkur district during kharif 2016-2018 under rainfed condition. Demonstration was conducted in 25 ha area in three villages involving 50 farmers. The soils of the demonstration fields were collected and analysed for its initial soil nutrients status. The results showed that the soils were slightly alkaline in soil reaction, non saline, low in nitrogen, medium in phosphorus and potassium nutrient content. Each demonstration was conducted in an area of 0.4 ha and with an adjacent area of 0.4 ha selected for farmers practice. In the demonstration, the improved practices including cultivation of finger millet variety ML 365, integrated nutrient management, integrated pest and disease management practices were demonstrated along with the farmers practice.

Finger millet variety ML 365 was released from University of Agricultural Sciences, Bengaluru during 2008. It has 100-105 days duration, high yielding variety, tolerant to drought and blast disease. In farmers practice, finger millet variety GPU 28 was grown with the existing farm-ers practices such as broadcasting of seeds, basal application of complex fertilizers, etc. The details on the technological interventions followed in the demonstration and farmers practice were given in Table 1. Before initiating the demonstration, the beneficiary farmers were trained in all the improved practices in finger millet cultivation and followed in the demonstrations. Demonstration field were periodically observed by the scientists of Krishi vigyan Kendra. 
At the time of harvest, the data on plant population (number), plant height $(\mathrm{cm})$, number of tillers per plant (number), days taken for $50 \%$ flowering (number) and grain yield ( $\mathrm{q} / \mathrm{ha})$ of finger millet crop were recorded from both the demonstration and farmers practice. Based on the cost of inputs and market price of the produce, economic parameters such as net return (Rs/ha) and benefit cost ratio were worked out.

\section{Results and Discussion}

Results of the study indicated that demonstration of drought and blast tolerant finger millet variety ML 365 with integrated crop management practices recorded the higher plant population $(35.5 / \mathrm{m} 2)$, plant height $(75.0 \mathrm{~cm})$ and higher number of tillers per plant (4.55). Lower plant population $(28.5 / \mathrm{m} 2)$, plant height $(64.5 \mathrm{~cm})$ and number of tillers per plant (2.5) were recorded in farmers practice (Table 2). The demonstrated variety attained maturity one week earlier than the existing local variety. Cultivation of drought tolerant finger millet variety ML 365 with integrated crop management practices recorded higher average grain yield of 23.61q/ha (Table 3). Farmers practice recorded lower average grain yield of $18.46 \mathrm{q} / \mathrm{ha}$. Adoption of improved practices increased the yield of finger millet to the tune of 28.16 per cent compared to the farmers practice under rainfed condition. The increased yield under demonstration might be due to the combined effect of high yielding, drought tolerant variety and adoption of improved crop management practices. The similar results of yield enhancement through front line demonstration of improved technologies has been reported by Kumar et al., (2010) in bajra; Solanki et al., (2014) in maize and Anand Naik et al., (2016) in sorghum. Besides, the incidence of blast disease was not reported in the demonstrated variety and it was 8 per cent in the farmers practice.

Table.1 Technological interventions followed in finger millet cultivation under FLD

\begin{tabular}{|c|l|l|l|}
\hline SI.No. & $\begin{array}{l}\text { Technological } \\
\text { interventions }\end{array}$ & Existing Farmers practice & $\begin{array}{l}\text { Improved practices demonstrated } \\
\text { through frontline demonstration }\end{array}$ \\
\hline $\mathbf{1}$ & Farming situation & Rainfed & Rainfed \\
\hline $\mathbf{2}$ & Variety & Cultivation of GPU 28 & Cultivation of ML 365 \\
\hline $\mathbf{3}$ & Time of sowing & First week of August & First week of August \\
\hline $\mathbf{4}$ & Method of sowing & $\begin{array}{l}\text { Broadcasting of seeds and } \\
\text { thinning operation was not } \\
\text { followed }\end{array}$ & $\begin{array}{l}\text { Broadcasting of seeds and spacing of 30 x } \\
10 \mathrm{~cm} \text { was followed by thinning and gap } \\
\text { filling operation }\end{array}$ \\
\hline $\mathbf{5}$ & Seed treatment practice & Not followed & $\begin{array}{l}\text { Seed treatment with Trichoderma@ 10g/kg } \\
\text { followed by biofertilizers viz., Azospirillum } \\
\text { and Phospho bacteria each @ 25g/kg }\end{array}$ \\
\hline $\mathbf{6}$ & Nutrient management & $\begin{array}{l}\text { Basal application of } \\
\text { 20:20:20 complex fertilizer } \\
\text { @ 125 kg/ha }\end{array}$ & $\begin{array}{l}\text { Basal application of FYM @ 12.5 t/ha; } \\
\text { Recommended dose of NPK @ 40:20:20 } \\
\text { kg/ha and Zinc sulphate @ 12kg and Boran } \\
5 \mathrm{~kg} / \mathrm{ha}\end{array}$ \\
\hline $\mathbf{7}$ & Weed management & Not followed & $\begin{array}{l}\text { One hand weeding on 25-30 Days after } \\
\text { sowing }\end{array}$ \\
\hline $\mathbf{8}$ & IPDM practices & $\begin{array}{l}\text { No prophylactic or control } \\
\text { measures for managing } \\
\text { pests and diseases }\end{array}$ & $\begin{array}{l}\text { Need based usage of plant protection } \\
\text { chemicals and IDM practices followed }\end{array}$ \\
\hline
\end{tabular}


Table.2 Growth parameters of finger millet varieties GPU 28 and ML 365 under FLD

\begin{tabular}{|l|l|l|l|l|}
\hline \multicolumn{1}{|c|}{ Treatments } & $\begin{array}{c}\text { Plant population } \\
\text { at harvest } \\
\text { (No./m2) }\end{array}$ & $\begin{array}{c}\text { Plant height } \\
\text { (cm) }\end{array}$ & $\begin{array}{c}\text { Number of } \\
\text { tiller per plant }\end{array}$ & $\begin{array}{c}\text { Days to 50\% } \\
\text { flowering }\end{array}$ \\
\hline Farmers practice (GPU 28) & 28.5 & 64.50 & 2.50 & 65 \\
\hline $\begin{array}{l}\text { Demonstration of improved } \\
\text { practices (ML 365) }\end{array}$ & 35.5 & 75.0 & 4.55 & 70 \\
\hline
\end{tabular}

Table.3 Yield performance of finger millet varieties ML 365 and GPU 28 under FLD

\begin{tabular}{|l|l|c|c|c|c|c|}
\hline \multirow{2}{*}{ Year } & Name of the Block/Village & No. of & Area & \multicolumn{2}{|c|}{ Yield (q/ha) } & \multicolumn{2}{c|}{ \% change in } \\
& & Farmer & (ha) & ML-365 & GPU-28 & yield \\
\hline 2016 & Shivaramanahally, Tiptur Tq & 25 & 10 & 22.50 & 17.40 & 29.31 \\
\hline 2017 & Guddenahally, Tiptur Tq & 10 & 5 & 26.85 & 21.50 & 24.88 \\
\hline 2018 & Doddamadure, Kunigal Tq & 25 & 10 & 21.50 & 16.50 & 30.30 \\
\hline Mean & - & & & 23.61 & 18.46 & 28.16 \\
\hline
\end{tabular}

Table.4 Cost economics of economics of finger millet varieties GPU 28 and ML 365 under FLD

\begin{tabular}{|l|c|c|c|c|c|c|c|c|}
\hline \multirow{2}{*}{ Year } & \multicolumn{3}{|c|}{$\begin{array}{c}\text { Economics of Demonstration } \\
\text { variety ML-365 (Rs./ha) }\end{array}$} & \multicolumn{3}{c|}{$\begin{array}{c}\text { Economics of Economics of check } \\
\text { variety GPU-28 (Rs./ha) }\end{array}$} \\
\hline & $\begin{array}{c}\text { Gross } \\
\text { Cost }\end{array}$ & $\begin{array}{c}\text { Gross } \\
\text { Return }\end{array}$ & $\begin{array}{c}\text { Net } \\
\text { Return }\end{array}$ & BCR & Gross & $\begin{array}{c}\text { Gross } \\
\text { Cost }\end{array}$ & $\begin{array}{c}\text { Net } \\
\text { Return }\end{array}$ & BCR \\
Return & \\
\hline 2016 & 27214 & 54478 & 27264 & 2.36 & 27357 & 41543 & 14186 & 1.90 \\
\hline 2017 & 21200 & 59070 & 37870 & 2.97 & 20550 & 47300 & 26750 & 2.30 \\
\hline 2018 & 23500 & 62350 & 38850 & 2.65 & 22500 & 47850 & 23350 & 2.12 \\
\hline Mean & 23971 & 58632 & 34661 & 2.66 & 23469 & 45564 & 21428 & 2.10 \\
\hline
\end{tabular}

The data on economic indicators indicated that, the cost of production was higher in demonstration (Rs. 23971/ha) and lower in farmers practice (Rs. 23464/ha) (Table 4). Farmers earned the net income of about Rs.34661/ha through the cultivation of ML 365 variety with integrated crop management practices and Rs.21428/ha with farmers practice. On an average Rs. 13233/ha as additional income is attributed to the higher yield obtained in demonstration. Hence, farmers realized the higher benefit cost ratio (2.66) through the cultivation of ML 365 variety with integrated crop management practices compared to farmer's practice (2.10). It might be due to the higher grain yield recorded in demonstration compared to farmers practice. Similar results of increase in net income and benefit cost ratio due to adoption of improved technologies in the demonstrations were reported by Jat and Gupta (2015) in pearl millet; Dhaka et al., (2010) in maize and Anand Naik et al., (2016) in sorghum.

Results of the demonstration revealed that cultivation of finger millet variety ML 365 with integrated crop management practices increased the yield and income of the farmers under rainfed condition. In addition, the introduced variety has satisfied the farmers preferences such as high tiller production, early maturity and tolerance to grain shattering or dusting. 
Hence, the farmers were convinced with the performance of the variety with regard to its yield potential and tolerance to biotic and abiotic stresses under rainfed condition.

\section{References}

Anand Naik, Raju, G., Teggelli, Zaheer Ahamed, B. and Devappagouda H. Patil. 2016. Yield gap analysis of sorghum through front line demonstrations in Kalaburagi region of northern Karnataka. Res. Environ. Life Sci., 9(5): 597-598.

Chethan, S. and Malleshi, N.G. 2007. Finger millet polyphenols: characterization and their nutraceutical potential. Am. J. Food Technol., 2 (7): 582-592.

Devi, P.B., Vijayabharathi, R., Sathyabama, S., Malleshi, N.G. and Priyadarisini, V.B. 2014. Health ben-efits of finger millet (Eleusine coracana L.) polyphenols and dietary fibre: a review. J. Food Sci. Technol., 51(6): 1021-1040

Dhaka, B.L., Meena, B.S. and Suwalka, R.L. 2010. Popularization of improved maize production technology through frontline demonstrations in south-eastern Rajasthan. Journal of Agricultural Science, 1(1): 3942.

Jat, B. L. and Gupta, J. K. 2015. Yield gap analysis of pearl millet through frontline demonstrations in Dausa district of Rajasthan. Karnataka. J. Agric. Sci., 28(1): 104-106.

Kumar, A., Kumar, R., Yadav, V.P.S. and Kumar, R.A. 2010. Impact assessment of frontline demonstrations of bajra in Haryana state. Indian Res. J. Ext. Edu., 10 (1): 105-108.
Meena, B. L., Meena, R. P., Meena, R. R., \& Singh, B. (2014). Popularization of improved maize (Zea mays L.) production technology through frontline demonstrations in semi arid zone IVA of Rajasthan. Journal of Applied and Natural Science, 6(2), 763-769.

Okalebo, J.R., Jutto, P.M. and Gathera, K.W. 1991.Effect of form and method of phosphate fertilizer application on maize, sorghum and millet growth in semi-arid environment of Kenya. II. Effect of bulrush and finger millet. East African Forestry Journal, 55: 239-248.

Sharma,V., Vijay Kumar, Sharma, S.C. and Sukhvinder Singh. 2016. Productivity enhancement and popularization of improved production technologies in wheat through frontline demonstrations. Journal of Applied and Natural Science, 8 (1): 423-428.

Singh, S.B. 2017. Impact of frontline demonstrations on yield of wheat (Triticum aestivum) under rain fed condition in Uttarakhand. International Journal of Science, Environment and Technology, 6(1): 779 - 786.

Solanki, R.L., Rathore, R.S., Dhakar, S.D. and Kanojia, Y. (2014). Yield gap analysis of integrated nutrient management in maize through front line demonstration. International Journal of Plant Sciences, 9(2): 438-440.

Subhashree, K.S., Ravishankar, C.R., Raveendra, H.R., Madhusudhan, K. 2017. Economic impact of front line demonstrations on finger millet yields. Agriculture Update, 12(1): 169-171.

\section{How to cite this article:}

Shreenivasa, K. R., T. S. Sukanya and Govinda Gowda, V. 2020. Performance of Blast and Drought Tolerant Finger Millet Variety ML-365 under Front Line Demonstrations in Tumkur, Karnataka. Int.J.Curr.Microbiol.App.Sci. 9(12): 521-525. doi: https://doi.org/10.20546/ijcmas.2020.912.061 